\title{
The Effect of Using 'Microb' Mobile Application in Science Learning in Primary School
}

\author{
https://doi.org/10.3991/ijim.v16i02.27307 \\ Mogana A/P Tachinamutu ${ }^{1}$, Mohd Nihra Haruzuan Bin Mohamad Said(区) \\ Zaleha Binti Abdullah², Mohd Fadzli Bin Ali², Lokman Bin Mohd Tahir ${ }^{2}$ \\ ${ }^{1}$ Maktab Sultan Abu Bakar, Johor Bahru, Malaysia \\ ${ }^{2}$ Universiti Teknologi Malaysia, Johor Bahru, Malaysia \\ nihra@utm.my
}

\begin{abstract}
The study investigated the relationship between the overall scientific performance of the pre-test and post-test and the impact of the application of "Microb" on scientific performance. The theme is "microorganisms and their effects". The sample group consisted of 30 . Year 5 pupils' from a primary school in Johor Bahru. They were selected for this quantitative study through purposeful sampling. Investigation, pre-test and post-test are used to collect research data. The results show that based on the four science constructs, year 5 pupils' acceptance of the "Microb" mobile application is very high. According to the survey results, although there is no relationship between the two overall performance tests and no impact was found in the research, it was found that the "Microb" mobile application has a positive impact on the scientific performance of year 5 pupils', based on the construct of scientific process skills, understanding, application and knowledge. The results of this research will make an important contribution to the field of education and provide new options for choosing the "Microb" mobile application as an educational tool to strengthen science education. In general, the "Microb" mobile application in technology can be a good educational tool for scientific learning, but educators must organize lesson plans well and not deviate from the focus of learning.
\end{abstract}

Keywords—-mobile application, Microb, science learning, primary school

\section{Introduction}

Technology is one of the most effective ways to increase students' knowledge. Since the introduction of mobile learning in Malaysia, the education system has made significant developments, especially in education technology. Mobile learning means learning on mobile devices, no matter where we are, we can do it anytime, anywhere. It emphasizes the ability to simplify the learning process, no matter where it is located, the learning process can still continue [3][5][11]. Android applications, which are mobile phone operating systems supported by the world's leading search engine company, Google Cooperation, have become indispensable communication tools for most people especially among students. Hence, teachers should take advantage of this opportunity by 
using Android applications, which are available as free resources for use in supporting their teaching. Android applications can increase students' interest and motivation, and its also affect students' direct participation in the learning process [9][10].

Android software is becoming more and more popular among smartphone users. Various applications have been loaded into the smart phone to meet the user's entertainment time and work needs. Therefore, the use of Android applications for technology and learning is necessary to run a more effective teaching and learning process. This application is suitable for use because students can learn according to their abilities. Students with poor grades can review their courses multiple times without waiting for the next class. Using apps in mobile devices in the education system is a transformation that accelerates the teaching and learning process based on technological concepts.

The following is the Cognitive Theory-based conceptual framework that was applied in this research. Mayer's Cognitive Idea of Multimedia Learning is largely crucial to the formation of this theory (Figure 1). In general, this approach tries to address how to structure multimedia teaching practices and engage more effective cognitive methods to assist people learn more effectively. Year 5 pupils' were assessed on the 'Microb' mobile application, which was based on the Cognitive Theory of Multimedia Learning.

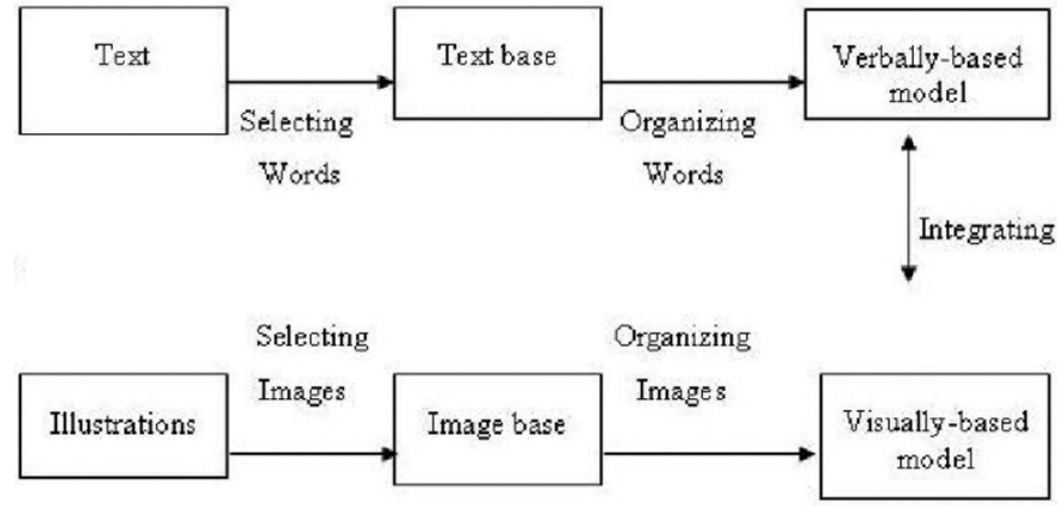

Fig. 1. Conceptual framework based on the cognitive elements of mayer multimedia learning

\section{$2 \quad$ Literature review}

In this section, various results from previous investigations and reference materials are used. This section also defines numerous key terms used in this study, including pedagogy, learning systems, educational system development, educational technology, and m-learning applications (advantages and future prospects).

\subsection{Problems of mastery of science subjects}

Students' knowledge of science and mathematics subjects has been diminishing since English has been emphasized in education, particularly in science and mathematics. 
By boosting the performance of school children in science examinations, the government tries to enhance a scientifically minded and innovative society. The attitude of students is the key to academic achievement, especially in science. However, science subjects are often considered difficult to understand and very complex. This phenomenon must be eliminated so as not to affect the improvement of science subjects in our schools and education system. Students very much need to have a profound and positive attitude towards scientific subjects in order to increase their understanding of abstract scientific concepts and decide to achieve greater success in science in the future.

According to a study conducted by [10-13], respondents who are not interested in science and lack self-confidence are the reasons for their decline in academic performance. The research conducted has concluded that students are now not concerned about the science in their lives. Boring scientific contact with students can cause problems in science learning. Through the mobile application called "Microb", students will be more interested in learning science, especially microorganisms topics. This is because creative elements are applied in the app, such as game-based learning and quizzes. They will have more fun learning science because the teaching methods presented are no longer boring. In addition to using mobile device applications in the learning process can increase students' mastery and more effective understanding of the latest information technology.

\subsection{The effectiveness of the use of mobile applications in teaching and learning}

A major innovation in information technology systems today is the mobile device. The communication technology revolution has brought consumers many benefits, like changing their size.. As a result, communication devices are smaller in size and lighter to carry, compared with the past when mobile phones or mobile devices were large and cumbersome. Communications tools have improved such that users can easily carry their phones wherever they go. A large part of the acceptance of mobile devices in today's world is the ability to surf the Internet without the use of a computer or Internet connection [4][7][10][12]. Using mobile devices in education can encourage students to share information and collaborate through online learning. Moreover, [5], [12] also proved in their research that mobile-based learning or mobile self-learning has applications beyond classrooms, where the learning process can be conducted anywhere. The availability of an internet connection allows students to study at home, in the garden, in the library, or anywhere, without having to interact with teachers or classmates.

In addition, the use of mobile device applications in the teaching system can stimulate students' interest in deepening their knowledge. Among the advantages described in [19], students are easy to use because most of the menus and instructions in the phone are user-friendly. In addition, it can also help students not feel embarrassed when studying, because online learning has the concept of "single". This can help students continue to share ideas without having to face everyone, and can make them more active in their studies. According [11] pointed out that Islamic education teachers and students accept the use of mobile phones as mobile learning because it can help them discuss, teach and learn, such as doing homework through text messages between teachers and 
students. Through this 'Microb' application, students and teachers only need to download the provided application to learn about microorganisms and their effects on organisms anytime and anywhere. This learning method is more effective because students and teachers get all the teaching and learning materials in one application.

\subsection{Science learning approach through interactive multimedia application}

Education is also being affected by the rapid growth of interactive multimedia technology, particularly in teaching. Among the advantages of using multimedia in the teaching process are the benefits of incorporating text, audio, video, graphics, and animation into the process. Further, multimedia can also include elements that stimulate the use of many human senses and support multi-sensory learning. Multimedia encourages interactivity and gives users control over the way the media is used. The use of multimedia technology can send a large amount of information to students. The information can be accessed and used according to the student's own time and place [8].

Multimedia is also considered to be an active and effective communication medium, because text, audio, video, and animation in various colors and patterns are simultaneously displayed on the screen. Moreover, compared to the use of static and silent materials, the use of interactive media can also attract users' interest and attention, and is easy to understand [18]. Interested users will pay more attention to the content or information delivery, which will make the information delivery process more effective and efficient. All this proves that multimedia is very suitable for use in the teaching process. It turns out that the use of multimedia elements can form a higher level of understanding and skills among students. In addition to providing more information, multimedia based learning methods enable students to retain more complicated information or contents.

The use of multimedia in teaching and learning can encourage students to think critically and creatively in solving problems, finding and organizing information that can motivate students to learn. In addition to cooperative and collaborative learning, it also encourages active learning among students. On the other hand, this will indirectly provide students with the skills they need in real life, especially in their future careers [19]. When students have the opportunity to actively participate in learning activities, they will find that the learning process is more interesting and satisfying than the passive learning process [11]. In this case, the student's learning process will be strengthened individually or through cooperation between group members. Such a learning environment can also prepare students for interaction or behavior to deal with higher-level learning processes.

\subsection{Learning theory}

Analysts express that learning hypothesis is a mix of speculations that clarify the motivation behind realizing, how learning is cultivated, just as elements that impact learning meetings. The learning hypothesis applied in the advancement of this 'Microb' mobile application is the Cognitive Theory of Multimedia Learning. Multimedia as a combination of text, audio, images, animation, and video Computing education has 
focused instructional design principles based on Multimedia Learning Cognitive Theory. Beginning with paper-based teaching materials, these guidelines and principles have been expanded with the introduction of computers and multimedia teaching materials that are integrated with the learning environment.

\subsection{Model design}

This 'Microb' mobile learning application is developed according to the ADDIE model because, this model includes 19 steps for program development and training. The measures were divided into five phases, namely, analyses, designs, developments, implementations, and evaluations. The development of Microb applications is based on the objectives established at the beginning of the study. The theory, model, and method used for the development should be carefully chosen. Therefore, the developer chose cognitive learning theory for the development of this application because it allows students to form their own style of thinking that is in line with this 'Microb' application, which requires students to form answers to questions based on existing knowledge.

\section{$3 \quad$ Method}

\subsection{Research sample}

In this study, the samples were selected using non-probability and purposive sampling techniques. The samples were being chosen from a primary school in the District of Johor Bahru. In this research, there are total of 30 pupils will be selected as the sample to be an indication of the pupils' performance and perceptions in Johor Bahru district. Students in Year 5 with similar ICT backgrounds are being selected to participate in the sample set. According to the non-probability sampling approach, samples are anonymous and confidential in order to meet the requirements for ethics in research.

\subsection{Research approach}

The researcher chose a quantitative approach for this research. A quantitative study is a method of measuring and analyzing variables with the aim of obtaining data and a numerical result of a study [1]. A quantitative study is a method of measuring and analyzing variables with the aim of obtaining data and a numerical result of a study [1]. Pre-experimental design is being used in this study. There is a sample group of Year 5 pupils who are going to undergo pre-test and post-testing in order to determine initial marks and the effects of Microb application on the target group after one month of usage in Science learning. This study uses a purposive sampling method to select a sample group. The purpose of the pre-test evaluation is to identify the needs and standards of the sample group. Before the actual research was conducted, a preliminary study was carried out on a small scale to improve the prior study design and test the validity and reliability of the items in the questionnaire. The aim of this study is to obtain data on pupils' perceptions of Microb application in Science learning based on the four construct science (Science process skills, understanding, application, and 
knowledge) after the samples have experienced 'Microb' application for a month. The researcher used the questionnaire to conduct this process.

\subsection{Research instruments}

The researcher used two main types of instruments to collect the data from the samples for this study. Pre-test assessment, post-test assessment, and survey questionnaire comprise the main instruments. By integrating Microb mobile application for about one month, the pre-test and post-test were carried out based on the learning content from the Science lessons. A pre-test will be given to the research samples before the treatment begins, and a post-test will follow after the samples have experienced the lessons. Specifically, the questionnaire will ask for the samples' perceptions on how they perceive the impact of Microb applications on their science learning. The questionnaire was consist of two parts (Part A and Part B). Twelve sets of questionnaires were distributed to the pilot test sample group which included 12 pupils, before the actual study began. Students who filled out the paper questionnaire were randomly selected Year 5 students from 12 primary schools with similar ICT background characteristics as the actual research samples. After the experience session, responses were being collected. A Cronbach's alpha value of 0.814 in the pilot test represents a high level of interval consistency for the scale. Based on these results, this questionnaire is suitable for use in the study.

\subsection{Pre-test and post-test}

In order to answer the research questions, pre-tests and post-tests were distributed to the sample group. It is intended to identify the effect of Microb mobile application on primary pupils' Science performance by having a pre-test and post-test. Researcher will test research samples on relevant learning content from the latest syllabus using Microb mobile applications based on the four basic science construct skills (Science process skills, understanding, application, and knowledge). Both tests were validated by two experienced Science teachers in order to ensure the questions are appropriate for Year 5 students. In order to standardize the marks given for these two tests, transcripts and grading guides had been developed for both.

\subsection{Survey}

As part of this study, the researcher created a survey in the form of a questionnaire that was used to collect the data from the research samples. A questionnaire consists of items related to primary pupils' perceptions of Microb mobile applications in Science learning based on four construct science, including science process skills, understanding, application and knowledge. The questionnaire was being transferred to Google Form. In order to guide respondents to complete the questionnaire, instructions and guidance will be provided throughout the survey. Table 1 showed related items in the questionnaire. 
Table 1. Parts and quantity of related items consists in the questionnaire

\begin{tabular}{|c|l|c|}
\hline No. & \multicolumn{1}{|c|}{ Section } & \multicolumn{1}{|c|}{ Items } \\
\hline 1 & Part A: The demographic background & 5 items \\
\hline 2 & $\begin{array}{l}\text { Part B: Section 1: Perceptions on mobile application Microb based on Science } \\
\text { process skills }\end{array}$ & 5 items \\
\hline 3 & Part B: Section 2: Perceptions on mobile application Microb based on Understanding & 5 items \\
\hline 4 & Part B: Section 3: Perceptions on mobile application Microb based on Application & 5 items \\
\hline 5 & Part B: Section 4: Perceptions on mobile application Microb based on Knowledge & 5 items \\
\hline & Total & 25 items \\
\hline
\end{tabular}

To ensure the validity of the questionnaire that researcher was developing in accordance with the research needs, two senior and experienced lecturers from the researcher's university were invited to review it. A sample of 30 respondents was asked to read each statement carefully and rate it on a 4-point Likert scale. The meaning of each scale as in Table 2.

Table 2. Scale and meaning of the scale in the questionnaire

\begin{tabular}{|c|l|}
\hline Scale & \multicolumn{1}{c|}{ Meaning } \\
\hline 1 & Strongly Disagree \\
\hline 2 & Disagree \\
\hline 3 & Agree \\
\hline 4 & Strongly Agree \\
\hline
\end{tabular}

\section{Data analysis}

PSPP GNU software is used to descriptively and inferentially analyze the raw data collected after the data collection process. After calculating, summarizing, and interpreting the data, the data will be used in the study.

\subsection{Analysis of primary pupils' perception}

The sample group filled out questionnaires with a 4-point Likert scale as part of the study. The items are scored on an ordinal scale. In this part of the study, a descriptive analysis will be used to analyze primary pupils' attitudes towards 'Microb' application. There are mean values and standard deviations calculated for each item for both constructs. Based on the scale and range of each construct, total scores are classified into four categories of interpretation as in Table 3 . 
Table 3. 4-point Likert scales, range and categories of interpretation

\begin{tabular}{|l|l|l|}
\hline \multicolumn{1}{|c|}{ Scale } & Range & \multicolumn{1}{c|}{ Categories of Interpretation } \\
\hline Strongly Disagree (1) & $1.0-1.4$ & Very low \\
\hline Disagree (2) & $1.5-2.4$ & Low \\
\hline Agree (3) & $2.5-3.4$ & High \\
\hline Strongly Agree (4) & $3.5-4.0$ & Very High \\
\hline
\end{tabular}

\subsection{Analysis of primary pupils' science learning performance}

To determine the comparison of the significance correlated level of the research samples, the final scores of the pre- and post-test were analyzed with inferential statistics. In order to test the normality of the data, the Shapiro-Wilk normality test was conducted before deciding on the statistical analysis. To run the process of data analysis, a parametric test, such as the paired sample t-test (Data is normally distributed.) or Wilcoxon signed-rank test (Data is not normally distributed.), was selected Finally, the researcher then computed Cohen's d for paired sample t-tests in order to identify the difference between the variables for improving the accuracy of the study.

\subsection{Analysis relationship between primary pupils' English overall performance before and after using mobile application 'Microb'}

Shapiro-Wilk normality test is being used in this analysis. A Pearson's correlation coefficient (Data is normally distributed) or a Spearman's rank-order correlation coefficient (Data is not normally distributed) is used to identify the relationship between primary pupils' Science overall performance in their pre-test and post-test. According to Cohen (1988), an absolute value (r) of 0.5 is large, an absolute value (r) of 0.3 is medium, and an absolute value (r) of 0.1 is small.

Analysis Influence of Mobile Application Before and After Utilizing 'Microb' on Year 5 Pupils' Science Overall Performance in Topic Microorganism and its Importance. In this analysis, the data of the overall score of the pre-test and the overall score of the post-test is analyzed using simple linear regression. The purpose of this study is to determine whether the application 'Microb' affects the overall performance of year five pupils in Science. The results is presented in a scatterplot chart in this analysis.

\section{$5 \quad$ Results}

This section discusses and analyzes the data obtained from the 30 sets of questionnaires, 30 sets of pre-tests, and 30 sets of post-tests that were administered to the 30 samples of the study. In this study, the aim was to determine whether mobile application 'Microb' affects primary pupils' learning performance in four constructs Science. PSPP GNU software was used to generate the related data and results for the study. 


\subsection{Year 5 pupils perception on 'Microb' mobile application in science learning}

Based upon the findings presented in this subchapter, the research aimed to address the first objective of the study, which was to investigate Year 5 pupils' perceptions of the Microb mobile application in Science learning. From the survey, 30 respondents gave their opinions on the perception of acceptance of the Microb mobile application in their Science education, using a 4-point Likert scale (Strongly Disagree, Disagree, Agree and Strongly Agree). Part B of the survey consists of 20 items. Item categories were separated into four parts ( 5 items per part), which focused on four construct Science.

Table 4. Item's mean value and standard deviation based on construct science process skills

\begin{tabular}{|c|l|c|c|}
\hline No & \multicolumn{1}{|c|}{ Item Based on Science Process Skills } & Mean & $\begin{array}{c}\text { Std. } \\
\text { Deviation }\end{array}$ \\
\hline 1 & $\begin{array}{l}\text { Microb applications helped me improve my understanding of questions } \\
\text { involving science process skills. }\end{array}$ & 3.63 & .49 \\
\hline 2 & $\begin{array}{l}\text { I feel more confident answering questions in the form of science process } \\
\text { skills by using Microb applications. }\end{array}$ & 3.43 & .63 \\
\hline 3 & $\begin{array}{l}\text { I feel Microb applications help me focus on answering questions that are } \\
\text { guided by science process skills. }\end{array}$ & 3.30 & .60 \\
\hline 4 & $\begin{array}{l}\text { I feel the scores given in Microb applications increase my interest in } \\
\text { answering questions in the form of science process skills. }\end{array}$ & 3.33 & .66 \\
\hline 5 & $\begin{array}{l}\text { I was able to answer questions involving experiments after using Microb } \\
\text { applications. }\end{array}$ & 3.47 & .51 \\
\hline & Overall & 3.54 & .53 \\
\hline
\end{tabular}

As shown in the table above, respondents considered Microb applications for science learning based on construct science process skills is to be acceptable. As seen in Table 4, the overall mean was 3.54, which was the highest mean, and the standard deviation was 0.53 . Among all items in this section, the first item with the highest mean was 3.63 and the standard deviation was 0.49 , indicating that the respondents felt 'Microb' applications helped them improve their understanding of questions involving construct science process skills. Next, the fifth item which stated that 'I was able to answer questions involving experiments after using Microb applications,' had the mean value of 3.47 which was the second highest and standard deviation of 0.51 . Followed by the second item that stated 'I feel more confident answering questions in the form of science process skills by using Microb applications' which the mean was 3.43 with the standard deviation was 0.63 . The forth items that stated 'I feel the scores given in Microb applications increase my interest in answering questions in the form of science process skills' which the mean was 3.33 and the standard deviation for this item was 0.66 . The statement with a mean of 3.30 , which was the lowest mean with a standard deviation of 0.60 in this section, was 'I feel Microb applications help me focus on answering questions that are guided by science process skills'. 
Table 5. Item's mean value and standard deviation based on construct knowledge

\begin{tabular}{|c|l|c|c|}
\hline No & \multicolumn{1}{|c|}{ Item Based on Construct Knowledge } & Mean & $\begin{array}{c}\text { Std. } \\
\text { Deviation }\end{array}$ \\
\hline 1 & $\begin{array}{l}\text { Microb applications helped me improve my understanding of questions } \\
\text { involving knowledge. }\end{array}$ & 3.53 & .51 \\
\hline 2 & $\begin{array}{l}\text { I feel more confident answering questions in the form of knowledge by } \\
\text { using Microb applications. }\end{array}$ & 3.37 & .56 \\
\hline 3 & $\begin{array}{l}\text { I feel Microb applications help me focus on answering questions that are } \\
\text { guided by knowledge. }\end{array}$ & 3.60 & .50 \\
\hline 4 & $\begin{array}{l}\text { I feel the scores given in Microb applications increase my interest in } \\
\text { answering questions in the form knowledge. }\end{array}$ & 3.47 & .63 \\
\hline 5 & $\begin{array}{l}\text { I was able to answer questions involving the effects of harmful } \\
\text { microorganisms on humans after use Microb applications. }\end{array}$ & 3.73 & .45 \\
\hline & Overall & 3.54 & .53 \\
\hline
\end{tabular}

Table 5 shows the mean value and standard deviation for part B of the questionnaire regarding pupils' acceptance of mobile apps and Microb applications in science learning based on construct knowledge. The mean was 3.54 and the standard deviation was 0.53 . Item 5 that collected the data about whether Microb application helps the respondents to answer questions involving the effects of harmful microorganisms on humans had gained the mean of 3.73 which was the highest mean and the standard deviation was 0.45 among the other items in this section. Item 3 that stated 'I feel Microb applications help me focus on answering questions that are guided by knowledge' was the item that gained the mean value of 3.60 which was the second highest and the standard deviation of 0.50 . Then, it followed by item 1 that stated 'Microb applications helped me improve my understanding of questions involving knowledge' with the mean value 3.53 and the standard deviation 0.51 which was third highest. Item 4 that stated 'I feel the scores given in Microb applications increase my interest in answering questions in the form knowledge' had got the mean value of 3.47 and the standard deviation of 0.63 . Item 2 that stated 'I feel more confident answering questions in the form of knowledge by using Microb applications' gained the mean value of 3.37 which was presented as the lowest mean with the standard deviation of 0.56 compared to the other items in this section based on construct knowledge. 
Table 6. Item's mean value and standard deviation based on construct application

\begin{tabular}{|c|l|c|c|}
\hline No & \multicolumn{1}{|c|}{ Item Based on Construct Application } & Mean & $\begin{array}{c}\text { Std. } \\
\text { Deviation }\end{array}$ \\
\hline 1 & $\begin{array}{l}\text { Microb applications helped me improve my understanding of questions } \\
\text { involving application. }\end{array}$ & 3.53 & .51 \\
\hline 2 & $\begin{array}{l}\text { I feel more confident answering questions in the form of application by } \\
\text { using Microb applications. }\end{array}$ & 3.40 & .56 \\
\hline 3 & $\begin{array}{l}\text { I feel Microb applications help me focus on answering questions that are } \\
\text { guided by application. }\end{array}$ & 3.40 & .62 \\
\hline 4 & $\begin{array}{l}\text { I feel the scores given in Microb applications increase my interest in } \\
\text { answering questions in the form of application }\end{array}$ & 3.27 & .64 \\
\hline 5 & $\begin{array}{l}\text { I was able to answer questions that involve the prevention of infections } \\
\text { caused by Microbes. }\end{array}$ & 3.57 & .50 \\
\hline & Overall & 3.43 & .57 \\
\hline
\end{tabular}

According to the Table 6, the overall average is 3.43 and the overall standard deviation is 0.57 . Among all the items in this section, the fifth item has the highest average value of 3.57 and a standard deviation of 0.50 . This shows that the interviewees believed that these 'Microb' applications helped them answer questions related to the prevention of infections caused by Microbes. Next, the first item "Microb application helps me improve my understanding of issues involving construct applications" recorded the second highest average of 3.47 with a standard deviation of 0.51 , followed by the second item when using Microb applications, respondents feel more confident answering questions in the form of construct applications with standard deviation 0.56. and the third item with the statement "I feel that the Microb application helps me focus on answering application guidance questions" (standard deviation=0.62) have the same average. The value is 3.40. Finally, the fourth item with the statement 'I feel the score given in Microb applications increased my interest in answering questions based on construct application' recorded the lowest mean value of 3.27 with a standard deviation of 0.64 .

Table 7. Item's mean value and standard deviation based on construct understanding

\begin{tabular}{|c|l|c|c|}
\hline No & \multicolumn{1}{|c|}{ Item Based on Construct Understanding } & Mean & $\begin{array}{c}\text { Std. } \\
\text { Deviation }\end{array}$ \\
\hline 1 & $\begin{array}{l}\text { Microb applications helped me improve my understanding of questions } \\
\text { involving construct understanding. }\end{array}$ & 3.47 & .57 \\
\hline 2 & $\begin{array}{l}\text { I feel more confident answering questions in the form of understanding by } \\
\text { using Microb applications. }\end{array}$ & 3.30 & .53 \\
\hline 3 & $\begin{array}{l}\text { I feel Microb applications help me focus on answering questions that are } \\
\text { guided by understanding. }\end{array}$ & 3.63 & .49 \\
\hline 4 & $\begin{array}{l}\text { I feel the scores given in Microb applications increase my interest in } \\
\text { answering questions in the form of understanding }\end{array}$ & 3.30 & .60 \\
\hline 5 & $\begin{array}{l}\text { I was able to answer questions involving the role of beneficial } \\
\text { microorganisms in human life after using Microb applications. }\end{array}$ & 3.67 & .48 \\
\hline & Overall & 3.47 & .53 \\
\hline
\end{tabular}


From the last part of the survey related to construct understanding, Table 7 shows that the overall average for this part is 3.47 and the overall standard deviation is 0.53 . The item with the highest average value among the items in this section is item 5 . This item says "After using the Microb application, respondents can answer questions about the role of beneficial microorganisms in human life". Item 3 mentioned whether the Microb application helped the interviewees to focus on science construct understanding obtain an average mean 3.63 and a standard deviation of 0.49 . The result ranked second in this section. Item 1 stated that "Microb application helps respondents improve their understanding of questions involving construct understanding. The average mean value is 3.47 with standard deviation is 0.57 . Lastly followed by item 2 that stated 'I feel more confident answering questions in the form of understanding by using Microb applications (standard deviation=0.53) and item 4 with the statement 'I feel the scores given in Microb applications increase my interest in answering questions in the form of construct understanding' (standard deviation=0.60) had the same mean which was 3.30 in this section respectively.

\subsection{The effect of Microb mobile application on year 5 pupils' science performance based on four construct science}

The results of the analysis to find out the effect of Microb mobile application on Year 5 pupils' science performance based on the four Science construct which were being addressed in this subtopic. The effect of of 'Microb' mobile application on Year 5 pupils' Science performance based on construct science process skills were being addressed with the data collected. This research data was bringing a purpose to investigate whether there is a presence of significant difference between both of the tests which were stated as the research question for the study by using Wilcoxon signedranks test.

Table 8. Result of Wilcoxon signed-ranks test between science process skill pre-test and science process skill post-test

\begin{tabular}{|l|c|}
\hline & $\begin{array}{c}\text { Science Process Skills Post-test - } \\
\text { Science Process Skills Pre-test }\end{array}$ \\
\hline$Z$ & -2.383 \\
\hline Asymp. Sig. (2-tailed) & .017 \\
\hline
\end{tabular}

In Table 8, the Wilcoxon signed-rank test was used to analyze the raw data since the data is not normally distributed. Then, the results of the test proposed that the score of science process skills pre-test did elicit a statistically significant different with the score of science process skills post-test $(Z=-2.383, p=0.017)$. A study was conducted to see how 'Microb' mobile application affects Year 5 pupils' Science performance in based on construct knowledge. This data in the research was utilised to investigate whether there is a presence of significant difference betwixt the score in both of knowledge pretest and knowledge post-test which was listed as the research question for the study by conducting paired sample T-test. 
Table 9. Result of paired samples T-test between knowledge pre-test and knowledge post-test

\begin{tabular}{|c|c|c|c|c|c|c|c|c|c|}
\hline & \multicolumn{5}{|c|}{ Paired Differences } & \multirow{3}{*}{$\mathbf{t}$} & \multirow{3}{*}{ df } & \multirow{3}{*}{$\begin{array}{c}\text { Sig. } \\
\text { (2-Tailed) }\end{array}$} \\
\hline & & \multirow[t]{2}{*}{ Mean } & \multirow[t]{2}{*}{$\begin{array}{c}\text { Std. } \\
\text { Deviation }\end{array}$} & \multirow[t]{2}{*}{$\begin{array}{c}\text { Std. } \\
\text { Error } \\
\text { Mean }\end{array}$} & \multicolumn{2}{|c|}{$\begin{array}{c}95 \% \\
\text { Confidence } \\
\text { Interval of the } \\
\text { Difference }\end{array}$} & & & \\
\hline & & & & & Lower & Upper & & & \\
\hline Pair 1 & $\begin{array}{l}\text { Knowledge Pre-test- } \\
\text { Knowledge Post-test }\end{array}$ & -.667 & 2.998 & .547 & -1.786 & .453 & -1.218 & 29 & .233 \\
\hline
\end{tabular}

After using Shapiro-Wilk test to test the normality of the data, the data obtained are normally distributed. Therefore, the paired sample $\mathrm{T}$ test is used to analyze the scores of the knowledge pre-test and the knowledge post-test. According to Table 9, the Sig. (2-tailed) value is 0.233 and greater than $0.05(\mathrm{p}>0.05)$. This result shows that there is no significant difference in the scores of the two tests. Cohen's $d$ is also calculating the effect size. The result of $d$ is 0.308 , indicating that the effect size is very small. The collected data analyzed the impact of the Microb mobile application on the science performance of Year 5 pupils' based on the construct application. Use the obtained research data to find out whether there is a significant difference in the scores of the two. Wilcoxon signed rank test was used to analyze the data.

Table 10. Result of Wilcoxon signed-ranks test between construct application pre-test and application post-test

\begin{tabular}{|l|c|}
\hline & $\begin{array}{c}\text { Application Post-test - } \\
\text { Application Pre-test }\end{array}$ \\
\hline$Z$ & -3.910 \\
\hline Asymp. Sig. (2-tailed) & .000 \\
\hline
\end{tabular}

According to Table 10, the Wilcoxon signed rank test was used to analyze the data. This is because the data shown in the Shapiro-Wilk normality test is not normally distributed. The test results show that $Z=-3.910$ and Asymp. signal. The (2-tailed) value is 0.000 . Therefore, it means that a $\mathrm{p}$-value of 0.000 is less than $0.05(\mathrm{p}<0.05)$. Therefore, this finding is statistically significant. This proves that there is a significant difference between the scores of the two application tests.

In this chapter, data was collected on the impact of Microb mobile applications on Year 5 pupils' Science performance based on construct understanding. In this study, the data collected was used to determine whether there is a significant difference between the scores in both understanding tests. The Wilcoxon signed-ranks test was also used to analyze these data. 
Table 11. Result of Wilcoxon signed-ranks test between construct understanding pre-test and understanding post-test

\begin{tabular}{|l|c|}
\hline & $\begin{array}{c}\text { Understanding Post-test - } \\
\text { Understanding Pre-test }\end{array}$ \\
\hline$Z$ & -4.458 \\
\hline Asymp. Sig. (2-tailed) & .000 \\
\hline
\end{tabular}

Based on Table 11, Wilcoxon signed-rank test was being chosen to analyze the raw data. This is because the data were not normally distributed after being tested by the Shapiro-Wilk test of normality. The findings showed that $Z=4.458$ and the Asymp. Sig. (2-tailed) value was 0.000 . This result proposed that $p$ value of 0.000 is less than $0.05(\mathrm{p}<0.05)$. Consequently, the finding is statistically significant. This also verified that there is a presence of significant difference between the score from both of the understanding tests.

\subsection{The relationship between the year 5 pupils' science overall performance before and after using 'Microb' mobile application}

This subtopic presented the findings that being analyzed by using Pearson correlation on the Year 5 pupils' Science overall performance before and after using 'Microb' mobile application. The findings based on the overall score of pre- test and the overall score of post-test were being used to examine whether there is a relationship between both of the tests.

Table 12. Result of Pearson correlation between pre-test's overall score and post-test's overall score

\begin{tabular}{|l|l|c|c|}
\hline & & Overall Score of Pre-test & Overall Score of Post-test \\
\hline \multirow{3}{*}{$\begin{array}{l}\text { Overall } \\
\text { Score of Pre-test }\end{array}$} & Pearson Correlation & 1 & .310 \\
\cline { 2 - 4 } & Sig. (2-tailed) & & .096 \\
\cline { 2 - 4 } & $\mathrm{N}$ & 30 & 30 \\
\hline \multirow{2}{*}{$\begin{array}{l}\text { Overall } \\
\text { Score of Post-test }\end{array}$} & Pearson Correlation & .310 & 1 \\
\cline { 2 - 4 } & Sig. (2-tailed) & .096 & 30 \\
\cline { 2 - 4 } & $\mathrm{N}$ & 30 & \\
\hline
\end{tabular}

The Pearson correlation was utilized to analyze the raw data because the data were normally distributed. Table 12 presented the value of $p=0.960$ which was more than $\alpha=0.05$. There is no relationship between the overall score in both of the tests. There was a weak positive correlation between the pre-test's overall score and the post-test's overall score, which was not statistically significant $(r=0.310, n=30, p=0.096)$. 


\subsection{The influence of 'Microb' before and after utilizing on year 5 pupils' science overall performance on topic 'microorganism and its effects'}

The findings in this subchapter are to find out whether there is an influence of 'Microb' before and after utilizing on Year 5 pupils' Science overall performance on topic 'Microorganism and Its Effect'. Linear regression was being used to examine whether there is a presence of significant relationship betwixt the overall score in both of the tests as in Tables 13, 14 and 15.

Table 13. Model summary of simple linear regression analysis for the overall score of post-test and the overall score of pre-test

\begin{tabular}{|l|c|c|c|c|c|}
\hline Model & R & R Square & Adjusted R Square & Std. Error of the Estimate & Durbin-Watson \\
\hline 1 & $.310 \mathrm{a}$ & .096 & 0.64 & 4.296 & 2.330 \\
\hline
\end{tabular}

Note: a. Predictors: (Constant), Overall Score of Pre-test.

Table 14. ANOVA table of simple linear regression analysis for the overall score of post-test and the overall score of pre-test

\begin{tabular}{|c|l|c|c|c|c|c|}
\hline \multicolumn{2}{|c|}{ Model } & Sum of Squares & df & Mean Square & F & Sig. \\
\hline \multirow{2}{*}{1} & Regression & 54.761 & 1 & 54.761 & 2.967 & .096 \\
\cline { 2 - 7 } & Residual & 516.739 & 28 & 18.455 & & \\
\hline \multirow{2}{*}{} & Total & 571.500 & 29 & & & \\
\hline
\end{tabular}

Table 15. Coefficients table of simple linear regression analysis for the overall score of post-test and the overall score of pre-test

\begin{tabular}{|c|l|c|c|c|c|c|}
\hline \multirow{2}{*}{\multicolumn{2}{|c|}{ Model }} & \multicolumn{2}{|c|}{$\begin{array}{c}\text { Unstandardized } \\
\text { Coefficients }\end{array}$} & $\begin{array}{c}\text { Standardized } \\
\text { Coefficients }\end{array}$ & \multirow{2}{*}{ t } & \multirow{2}{*}{ Sig. } \\
\cline { 3 - 5 } & B & Std. Error & Beta & & \\
\hline 1 & (Constant) & 15.814 & 2.279 & & 6.939 & .000 \\
\hline & Overall Score of Pre-test & .265 & .154 & .310 & 1.723 & .096 \\
\hline
\end{tabular}

A simple linear regression was being conducted to analyze the post-test's overall score based on the pre-test's overall score. According to the tables above that presented the findings of the simple linear regression which showed that post- test concluded $9.6 \%$ of the variance, $(\mathrm{R} 2=0.096, \mathrm{~F}(1,28)=2.967, \mathrm{p}>.001)$. Hence, this result also can be proved by the following figure (Figure 2) which was the scatterplot that being plotted by using PSPP GNU. The slope line which lied on 0 showed that there is no presence of linear influence for the post-test's overall score and the pre-test's overall score with linear regression analysis. 


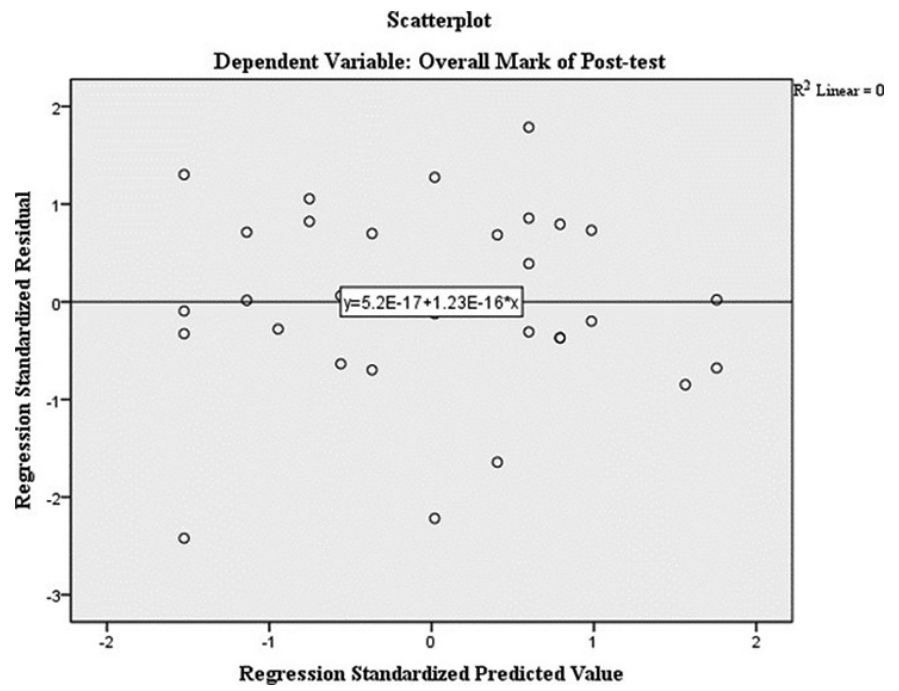

Fig. 2. Scatterplot of simple linear regression for the overall mark of post-test and the overall mark of pre-test

\section{Discussion}

From the perspective of the entire study, Year 5 pupils' have the highest positive response to the acceptance of "Microbe" mobile application in science learning based on the construct scientific process skills. This can be demonstrated by the statement "Microb applications help me improve my understanding of issues involving scientific process skills", which records very high averages mean and very low standards deviation compared to other items. This view is supported by [10], who stated that the use of apps in learning shows changes in students' thinking styles and promotes the process of transformation in learning. For the Year 5 pupils', the target sample also responded positively to the statement "I can answer questions involving experiments after using the Microb application", which recorded the second highest average reading and the second highest in the Standard deviation value. According to [10][19], the use of applications involving experiments can increase students' interest and understanding in learning Science. As a result of using Microb applications, students are more confident when answering questions related to science processes skills.

The last part of this study is, the level of acceptance of Year 5 pupils' towards the application of Microb in science learning based on understanding constructs. The fifth item stating "I can answer questions involving the role of beneficial microorganisms in human life after using Microb applications" got the highest mean value in this section. This proves that the respondents agree with the statement that the application of 'Microbes' helps them answer questions involving the role of beneficial microorganisms in human daily life. After Pearson correlation analysis was conducted, linear data regression analysis was performed using both pre-test and post-test overall data to determine whether there was an effect of using 'Microb' application on the 
overall performance of science learning in the topic of 'microorganisms and their effects' among Year 5 pupils'. The results showed that there was no effect of the use of 'Microb' application on the overall performance in science learning among Year 5 pupils'. It could be that this group of Year 5 pupils are new users, and that they need time to explore and adapt to this new way of learning to see the effect using 'Microb' applications on overall performance in science learning on topic 'Microorganism and its effect'.

\section{Conclusion}

In conclusion, based on this study, the mean value of the acceptability of 'Microb' application in science learning among Year 5 pupils' based on 4 constructs (science process skills, knowledge, application and understanding) is high. This shows that this 'Microb' application meets the needs and desires of users, which is to transform conventional learning methods into mobile application through mobile devices. This study can contribute to a new knowledge in the field of educational technology in Malaysia.

\section{$8 \quad$ Limitations and future studies}

A few limitations of this study should be further considered by other researchers in order to expand and enhance future research in this region. In this study, one of the limitations is that the focus of the study is on primary level science. The study range was limited and there are many levels and other constructs that could be explored further. Furthermore, the samples only included a small number of Year 5 pupils in Johor Bahru. Consequently, the findings of the study cannot represent all primary schools that used the 'Microb' application as a learning tool. The use of mobile applications is also not widespread in Malaysia's education system. Additionally, the study only focusing on the pupils' performance and perception on the acceptance of 'Microb' mobile application. The study does not consider the teacher's perspective. The 21 st century is being implemented in education today. Thus, the findings of this study can make an important contribution to the field of education in this era of technology. As a result of this study, a mobile application educational tool can also be used in science education to enhance the teaching and learning process. Future research on this area should extend in another direction that covers a broader range of the population. Future researchers are also urged to include the educators' perceptions or experiences regarding the 'Microb' mobile application.

\section{Acknowledgment}

We are grateful to Universiti Teknologi Malaysia and Malaysian Ministry of Higher Education for providing the grant (Vote No. 19J16) that enables this study to be carried out. 


\section{References}

[1] Apuke, O. D. (2017). Quantitative Research Methods: A Synopsis Approach. Kuwait Chapter of Arabian Journal of Business and Management Review, 6(11), 40-47. https://doi. org/10.12816/0040336

[2] Shchedrina, E., Galkina, E., Petunina, I., \& Lushkov, R. (2020). Integration of Mobile Learning into Complex Problem-Solving Processes during STEM Education. International Journal of Interactive Mobile Technologies, 14(21), 19-37. https://doi.org/10.3991/ijim. v14i21.18463

[3] Ismail Zain (2002). “Aplikasi Multimedia Dalam Pengajaran.” Utusan Publications \& Distributors Sdn. Bhd.

[4] Kirschner, P. A., Park, B., Malone, S., \& Jarodzka, H. (2017). Toward a Cognitive Theory of Multimedia Assessment (CTMMA). Learning, Design, and Technology: An International Compendium of Theory, Research, Practice, and Policy, 1-23. https://doi. org/10.1007/978-3-319-17727-4_53-1

[5] Mohd Yunos, M. A. A., Atan, N. A., Mohamad Said, M. N. H., Mokhtar, M., \& Abu Samah, N. (2017). Collaborative Learning in Authentic Environment Apps to Promote Preschool Basic Scientific Process Skills. International Journal of Interactive Mobile Technologies, 11(3), 4-15. https://doi.org/10.3991/ijim.v11i3.5774

[6] Motiwalla, L. F. (2007). Mobile Learning: A Framework and Evaluation. Computers and Education, 49(3), 581-596. https://doi.org/10.1016/j.compedu.2005.10.011

[7] Ratheeswari, K. (2018). Information Communication Technology in Education. India Journal of Applied and Advanced Research, 2018(3), 45-47. https://doi.org/10.21839/jaar.2018. v3iS1.169

[8] Robson, K., Plangger, K., Kietzmann, J. H., McCarthy, I., \& Pitt, L. (2015). Is it All a Game? Understanding the Principles of Gamification. Business Horizons, 58(4), 411-420. https:// doi.org/10.1016/j.bushor.2015.03.006

[9] Şahin, A. (2014). The Role of Information and Communication Technologies in Schools: Perspectives of Teachers. International Journal of Academic Research in Progressive Education and Development, 3(2), 112-124. https://doi.org/10.6007/IJARPED/v3-i2/919

[10] Saxena, N. (2017). The Role and Impact of ICT in Improving the Quality of Education. International Journal of Engineering Sciences \& Research Technology, 6(3), 501-503.

[11] Tahir, R., \& Arif, F. (2015). Mobile Technology in Children Education: Analyzing Parents' Attitude Towards Mobile Technology for Children. Proceedings of the 2015 Science and Information Conference, SAI 2015 (August 2018), 410-420. https://doi.org/10.1109/ $\underline{\text { SAI.2015.7237175 }}$

[12] Tin, T. G., Atan, N. A., Mohamad Said, M. N. H., Ali, M. F., Mohd, S., \& Abd Hamid, M. Z. (2018). Integrating Animations in Chinese Character Writing Based on Cognitive Theory of Multimedia Learning to Promote Students' Writing Skills. International Journal of Interactive Mobile Technologies, 12(7), 97-111. https://doi.org/10.3991/ijim.v12i7.9671

\section{Authors}

Mogana A/P Tachinamutu is postgraduate student at Universiti Teknologi Malaysia.

Mohd Nihra Haruzuan Bin Mohamad Said is a Malaysian Associate Professor specialize in Educational Technology at Universiti Teknologi Malaysia.

Zaleha Binti Abdullah is a Malaysian Associate Professor specialize in Educational Technology at Universiti Teknologi Malaysia. 
Mohd Fadzli Bin Ali is a lecturer specialize in Educational Technology at Universiti Teknologi Malaysia.

Lokman Bin Mohd Tahir is a Malaysian Associate Professor specialize in Educational Leadership at Universiti Teknologi Malaysia.

Article submitted 2021-09-05. Resubmitted 2021-10-25. Final acceptance 2021-10-26. Final version published as submitted by the authors. 